\title{
Control of Mixed Brush with Tebuthiuron
}

\author{
C.J. SCIFRES, J.L. MUTZ, AND W.T. HAMILTON
}

Highlight: Tebuthiuron pellets, 10 or $20 \%$ active ingredient, aerially applied at $2.24 \mathrm{~kg} / \mathrm{ha}$ active ingredient resulted in excellent control of whitebrush, spiny hackberry, and Berlandier wolfberry in South Texas mixed brush. At 2.24 to $3.36 \mathrm{~kg} / \mathrm{ha}$ active ingredient, the herbicide appears promising for control of lotebush, blackbrush acacia, ceniza, Texas colubrina, javalinabrush, guajillo, guayacan, desert yaupon and twisted acacia. Rates of 3.36 to $4.48 \mathrm{~kg} / \mathrm{ha}$ active ingredient, applied as tebuthiuron pellets, appeared promising on huisache but only partially controlled honey mesquite. Tebuthiuron was ineffective on lime pricklyash, Texas persimmon, pricklypear, and tasajillo.

Drift damage to adjacent agricultural crops from some herbicide sprays and the rigid timing requirements for foliar sprays have prompted investigation of dry herbicide formulations for brush management. Dry herbicides, pellets, or granules greatly reduce drift potential.

Soil applications of dry herbicides may extend the effective time span for control of woody plants compared to foliar herbicide applications. With conventional sprays of herbicides such as 2,4,5-T [(2,4,5-trichlorophenoxy)acetic acid] and 2,4,5-T + picloram (4-amino-3,5,6-trichloropicolinic acid), applications must be synchronized with foliar development of target species and specific environmental conditions conducive to maximum absorption and translocation of the herbicides. This restricts treatment for most woody plants to a relatively short period each spring or fall. Moreover, conventional sprays applied at the proper time for control of a species such as honey mesquite (Prosopis glandulosa var. glandulosa) may be only partially effective for control of many associated woody species.

Dry formulations of several herbicides have shown promise for control of some of the more important woody plants of South Texas, many of which are not highly susceptible to foliarapplied herbicides. Pelleted picloram effectively controls Macartney rose (Rosa bracteata) (Scifres 1975a), Texas persimmon (Diospyros texana) (Scifres 1975b), redberry juniper (Juniperus pinchoti) (Scifres 1972), lotebush (Condalia obtusifolia) (Scifres and Kothmann 1976), pricklypear (Opuntia spp.) (Hoffman and Dodd 1967), live oak (Quercus virginiana), huisache (Acacia farnesiana), and yaupon (llex vomitoria) (Bovey et al. 1969).

With the exception of relatively high rates of karbutilate |tertbuty]-carbamic acid ester with 3-(m-hydroxphenyl)-1,1dimethylurea] on certain soils, soil-applied herbicides have not appeared promising for control of honey mesquite (Scifres et al. 1977). A relatively new herbicide, tebuthiuron $[N-5-[1,1-$

The authors are professor, research associate and lecturer, Texas Agricultural Experi ment Station (Dept. of Range Science), Texas A\&M University, College Station 77843 Approved by the director, Texas Agr. Exp. Sta. as TA-13767

This research was supported in part by Lily Research Labs., Greenfield, Ind. The Chaparrosa Ranch, LaPryor; Leo Welder Ranch, Sinton; Dick Horton Ranch, Tilden; and Tom Haalf Ranch, Pearsall, Texas, provided land for the conduct of this research. Soil surveys of the LaPryor site by Michael Brown and Jack Stevens are appreciated. Manuscript received November 10. 1977 dimethylethyl]-1,3,4-thiadiazol-2-yl)- $N, N^{\prime}$-dimethylurea] has shown promise for control of several woody species which are serious range management problems (Bovey et al. 1975). The objective of this study was to evaluate the control of woody plants with aerial applications of tebuthiuron pellets to south Texas mixed-brush communities.

\section{Materials and Methods}

Tebuthiuron pellets ( $10 \%$ active ingredient and approximately 0.32 $\mathrm{cm}$ diameter) were aerially applied at $1.12,2.24,3.36$, and $4.48 \mathrm{~kg} / \mathrm{ha}$ active ingredient on May 15,1974 , to plots 31 by $322 \mathrm{~m}$ ( 1 ha) near LaPryor, Texas. The herbicide was applied with a spreader normally used for aerial-seeding and fertilizer application (Scifres 1977). Each treatment was duplicated in a randomized complete block design. Immediately after herbicide application, the experiment was fenced to exclude grazing by domestic livestock.

On May 22, 1975; June 21, 1976; and July 20, 1977, vegetation response was evaluated by stratifying the community into woody and herbaceous components. In 1975, woody plants were evaluated using the point-center quarter method (Cottam and Curtis 1956) for assessment of stand density, foliar cover, and community composition. At 25 points, equally spaced down the center of each plot, distance to the nearest plant in each quadrant was measured, species recorded, percentage canopy reduction visually estimated by two workers, and, if the plant was completely defoliated, presence or absence of vegetative sprouts was noted. Hereafter, plants completely defoliated and not resprouting will be referred to as "killed." In 1976 and 1977 , two workers estimated canopy reduction by species down the center of each plot.

Soil samples were recovered from the study area immediately after treatment for characterization of chemical and textural components. At each of three locations, samples were recovered from 0 to 8,8 to 15 , and 15 to $30 \mathrm{~cm}$ deep. Organic matter content by acid digestion and titration, $\mathrm{pH}$ on a 1:4, soil: water slurry, and textural components by the hydrometer method were determined on triplicate subsamples from each depth at each sampling location.

Since tebuthiuron was initially applied under experimental permit from the Environmental Protection Agency, it was required that grazing animals be excluded by fencing. Due to these and other constraints, it was not possible to duplicate the experiment near LaPryor. For example, $10 \%$ active ingredient pellets were available only for the LaPryor location. Sites were treated near Sinton, Tilden, and Pearsall, Texas, for comparative purposes using pellets containing $20 \%$ active ingredient. Tebuthiuron was aerially applied on September 25,1975 , near Sinton at 2 and $3.36 \mathrm{~kg} / \mathrm{ha}$. Herbicide was applied in 13.7-m wide swaths to plots 51.2 by $457.2 \mathrm{~m}$ ( $2.3 \mathrm{ha})$. An untreated plot was included for reference, and treatments were evaluated as described for the study near LaPryor in August 1975; June 1976; and July 15,1977

On November 20, 1975, tebuthiuron pellets were aerially applied at 1 and $2 \mathrm{~kg} / \mathrm{ha}$ to a whitebrush-dominated site near Tilden. Plots were 52 by $483 \mathrm{~m}$ ( $2.5 \mathrm{ha}$ ) and, as at Sinton, separated by untreated buffers 20.3 in wide. An untreated plot was included for comparison. On July 7, 1977, plots were evaluated as described for those near Sinton. The sites near Sinton and Tilden were fenced to exclude grazing by domestic livestock, and soil analyses were conducted as described for 


\section{the experiment near LaPryor.}

A final experiment was installed on the South Texas Plains near Pearsall to evaluate tebuthiuron for control of blackbrush acacia (Acacia rigidula) and guajillo (Acacia berlandieri), 1 to $1.5 \mathrm{~m}$ tall, which had been shredded 2 years previous to the experiment. On May 18,1976 , tebuthiuron was applied to 12.5 -by $40-\mathrm{m}$ plots at 1.5 and 4.4 $\mathrm{kg} /$ ha with a broadcast spreader attached to a rubber-wheeled tractor. The experiment was designed as a randomized complete block with each treatment duplicated. July 20, 1977, canopy reduction of individual plants and those completely defoliated and not resprouting were recorded in a transect $2 \mathrm{~m}$ wide down on the center of each plot.

\section{Soils, Vegetation and Rainfall on the Study Sites}

The soils of the study site near LaPryor were primarily Tonio sandy clay loam (fine loamy, mixed, hyperthermic Ustollic Haplargids) (Table 1) with interspersed Chacon clay loam. The Tonio series consists of deep, well-drained, moderately permeable soils. Solum thickness is 100 to $150 \mathrm{~cm}$ over weakly to strongly cemented sandstone.

Table 1. Characteristics of soil from study sites in South Texas where aerial applications of tebuthiuron pellets were evaluated for control of mixed brush.

\begin{tabular}{|c|c|c|c|c|c|}
\hline \multirow{2}{*}{$\begin{array}{l}\text { Depth } \\
\text { (cm) }\end{array}$} & \multirow[b]{2}{*}{$\mathrm{pH}$} & $\begin{array}{c}\text { Organic } \\
\text { matter }\end{array}$ & \multicolumn{3}{|c|}{ Textural components $(\%)$} \\
\hline & & $(\%)$ & Sand & Silt & Clay \\
\hline & & & \multicolumn{3}{|c|}{ Tonio series (LaPryor) } \\
\hline $0-8$ & 7.8 & 1.03 & 55 & 27 & 18 \\
\hline $8-15$ & 7.6 & 0.78 & 48 & 32 & 20 \\
\hline $15-30$ & 7.7 & 0.24 & 50 & 27 & 23 \\
\hline & & & \multicolumn{3}{|c|}{ Willacy series (Sinton) } \\
\hline $0-8$ & 6.2 & 1.52 & 69 & 13 & 18 \\
\hline $8-15$ & 6.3 & 1.28 & 70 & 13 & 17 \\
\hline $15-30$ & 6.5 & 0.86 & 66 & 12 & 22 \\
\hline
\end{tabular}

\section{Clareville series (Tilden)}

$\begin{array}{llllll}0-8 & 6.6 & 1.96 & 60 & 15 & 25 \\ 8-15 & 6.9 & 1.21 & 53 & 15 & 32 \\ 15-30 & 6.8 & 1.44 & 51 & 15 & 34\end{array}$

The study site near LaPryor was level to gently rolling and in fair range condition. The area supported an average of 405 horicy mesquite trees/ha, from 3 to $4 \mathrm{~m}$ tall, which formed the overstory. The most abundant woody species, guayacan (Porlieria angustifolia), constituted over one-third of the population density ( 750 plants/ha) but the plants rarely excecded $1 \mathrm{~m}$ tall. Other important species were whitebrush (Aloysia lycioides) (292 plants/ha), twisted acacia (Acacia tortuosa) (150 plants/ha), spiny hackberry (Celtis pallida) (136 plants/ha), and guajillo. Associated species ( 5 to 75 plants/ha) were catclaw acacia (Acacia greggii), blackbrush acacia, lotebush, Texas colubrina (Colubrina texensis), Texas persimmon, vine ephedra (Ephedra antisyphlitica var. antisyphlitica), leatherstem (Jatropha dioica var. dioica), allthorn (Koeberlina spinosa), Berlandier wolfberry (Lycium berlandieri var. berlandieri), javalinabrush (Microrhamnus ericoides), desert yaupon (Schaefferia cunefolia), and ceniza (Leucophyllum frutescens).

The area near LaPryor normally receives about $56 \mathrm{~cm}$ of rainfall annually. After application of the tebuthiuron on May 15, no rainfall was received until July 12 , when $1.78 \mathrm{~cm}$ fell over a 3-day period. Beginning in late August, rainfall was higher than normal with 49.58 $\mathrm{cm}$ received before January 1975 bringing the annual total to 58.09 $\mathrm{cm}$. Total precipitation was $42.49 \mathrm{~cm}$ in 1975 and $66.91 \mathrm{~cm}$ in 1976 . Rainfall was typically distributed in both years, with major peaks occurring in the spring (April-June) and fall (September-October). From January 1, 1977, to the final evaluation in August 1977, 23.51 $\mathrm{cm}$ of rainfall were received.

The soil of the Sinton study site was sandy loam to $30 \mathrm{~cm}$ deep over sandy clay loam to $60 \mathrm{~cm}$ deep. The soil was predominately of the Willacy series with minor inclusions of Sinton series. The Willacy series is a member of the fine-loamy, mixed, hyperthermic family of Udic Argiustolls.

The Sinton site was a gently sloping lowland supporting greater than $50 \%$ canopy cover of huisache with scattered honey mesquite, spiny hackberry, Texas persimmon, pricklypear, tasajillo (Opuntia leptocaulis), and lotebush. The 30-year average rainfall for the Sinton area is $72.5 \mathrm{~cm}$. Within a month following application of the tebuthiuron pellets in late September, $5.13 \mathrm{~cm}$ of rainfall were received. Total rainfall for 1975 was $64 \mathrm{~cm}$, and was $109 \mathrm{~cm}$ for 1976 . From January 1, 1977, until final evaluation in July $1977,47.9 \mathrm{~cm}$ of rainfall had been received on the study area.

Soil of the site near Tilden was of the Clareville series, a member of the fine, montmorillonitic, hyperthermic family of Pachic Arguistolls. Solum thickness is typically 75 to $150 \mathrm{~cm}$ with dark gray loam A horizons and clay loam Bt horizons. These soils are well drained with slow to medium surface runoff and are of moderately slow permeability. Soils of the immediate study site were sandy loams to $30 \mathrm{~cm}$ over clay loam.

The experiment near Tilden was located on a bottomland site supporting an almost solid cover of whitebrush with scattered honey mesquite, spiny hackberry, and lotebush plants. Only $1.55 \mathrm{~cm}$ of rainfall were received the first 60 days following tebuthiuron application near Tilden. However, $95.5 \mathrm{~cm}$ were received in 1976 with 24 $\mathrm{cm}$ occurring from March through June. From January 1, 1977, to final evaluation in July $1977,32.4 \mathrm{~cm}$ of precipitation occurred on the study area.

Soil of the Pearsall location was Olmos gravelly loam, a member of the loamy skeletal, carbonatic, hyperthermic, shallow family of Petrocalcic Calciustolls. These soils have a dark grayish brown A horizon with over $35 \%$ coarse fragments and are underlain by a thick bed of caliche at $30 \mathrm{~cm}$.

The experiment near Pearsall was located on an upland site supporting a mixture of blackbrush acacia and guajillo about $1 \mathrm{~m}$ tall. Rainfall was higher than normal, $105 \mathrm{~cm}$, in 1976 when compared to the average of the last 10 years, $72.7 \mathrm{~cm}$. The month after application of the tebuthiuron pellets, $20 \mathrm{~cm}$ of rainfall were received. During the 14 -month study period, $120 \mathrm{~cm}$ of rainfall occurred on the study area.

\section{Results and Discussion}

At 1 and 2 years after application of the 10\% tebuthiuron pellets near LaPryor, honey mesquite canopy was only slightly reduced with applications of 1.12 and $2.24 \mathrm{~kg} / \mathrm{ha}$ active ingredient (Table 2). Percentage canopy reduction of honey mesquite increased as tebuthiuron rate increased, regardless of evaluation date, with $54 \%$ of the canopy removed at 3 years after application of the high rate.

At 3 years after application, no honey mesquite were killed where the low rate of tebuthiuron was applied (Table 2). Percentage of the trees killed by $2.24 \mathrm{~kg} / \mathrm{ha}$ was not significant. At $3.36 \mathrm{~kg} / \mathrm{ha}, 16 \%$ of the honey mesquite were killed, and $34 \%$ of the trees were dead where the high rate was applied. However, response of honey mesquite to tebuthiuron was highly erratic within a rate of application. Completely defoliated trees were often within $10 \mathrm{~m}$ of trees with little or no canopy reduction.

Near Sinton, no canopy reduction of honey mesquite was apparent in July 1977 where $2 \mathrm{~kg} /$ ha active ingredient of the $20 \%$ tebuthiuron pellets were applied in late September 1975, and only $10 \%$ canopy reduction occurred where $3 \mathrm{~kg} / \mathrm{ha}$ were applied (data not shown). No honey mesquite control resulted in 
Table 2. Canopy reduction (\%) of honey mesquite, guayacan, twisted acacia, and guajillo at 1,2, and 3 years after aerial application of various rates (active ingredient) of pelleted tebuthiuron near LaPryor, Texas, 1974.

\begin{tabular}{|c|c|c|c|c|c|c|}
\hline \multirow[b]{2}{*}{ Species } & \multirow{2}{*}{$\begin{array}{l}\text { Year after } \\
\text { treatment }\end{array}$} & \multicolumn{5}{|c|}{ Tebuthiuron rate $(\mathrm{kg} / \mathrm{ha})^{1}$} \\
\hline & & 0 & 1.12 & 2.24 & 3.36 & 4.48 \\
\hline \multirow[t]{3}{*}{ Honey mesquite } & l & $0 a$ & $11 \mathrm{ab}$ & $23 \mathrm{bc}$ & $44 \mathrm{de}$ & $75 \mathrm{~g}$ \\
\hline & 2 & $0 \mathrm{a}$ & $14 \mathrm{ab}$ & $21 \mathrm{bc}$ & $63 \mathrm{ef}$ & $69 \mathrm{fg}$ \\
\hline & 3 & $0 \mathrm{a}$ & $6 a b$ & $22 \mathrm{bc}$ & $40 \mathrm{~cd}$ & $54 \mathrm{def}$ \\
\hline \multirow[t]{3}{*}{ Guayacan } & 1 & 0 a & $13 a b$ & $15 a b$ & $22 \mathrm{ab}$ & $21 \mathrm{ab}$ \\
\hline & 2 & $0 \mathrm{a}$ & $32 \mathrm{~b}$ & $57 \mathrm{c}$ & $73 \mathrm{c}$ & $76 \mathrm{c}$ \\
\hline & 3 & $0 \mathrm{a}$ & $17 a b$ & $62 \mathrm{c}$ & $70 \mathrm{c}$ & $72 \mathrm{c}$ \\
\hline \multirow[t]{3}{*}{ Twisted acacia } & 1 & () a & $40 \mathrm{bc}$ & $28 \mathrm{~b}$ & $72 \mathrm{~d}$ & $71 \mathrm{~d}$ \\
\hline & 2 & $0 \mathrm{a}$ & $32 \mathrm{~b}$ & $57 \mathrm{~cd}$ & $73 d$ & $76 \mathrm{~d}$ \\
\hline & 3 & $0 \mathrm{a}$ & $43 \mathrm{bc}$ & $58 \mathrm{~cd}$ & $70 \mathrm{~d}$ & $74 d$ \\
\hline \multirow[t]{3}{*}{ Guajillo } & 1 & $0 \mathrm{a}$ & $55 \mathrm{bc}$ & $76 \mathrm{cde}$ & 91 ef & $92 \mathrm{ef}$ \\
\hline & 2 & $0 \mathrm{a}$ & $47 b$ & $61 \mathrm{bc}$ & $98 \mathrm{f}$ & $94 \mathrm{ef}$ \\
\hline & 3 & $0 \mathrm{a}$ & $57 \mathrm{bc}$ & $67 \mathrm{bcd}$ & $70 \mathrm{~cd}$ & $84 \mathrm{de}$ \\
\hline
\end{tabular}

Meillu within a species followed by the same letter are non significantly different at the 95\%, |cicl

July 1977 where 1 or $2 \mathrm{~kg} / \mathrm{ha}$ active ingredient of the tebuthiuron pellets were applied in November 1975 near Tilden.

Although there was a trend for increasing canopy damage with increased tebuthiuron rate, no rate of tebuthiuron significantly reduced the canopy of guayacan at 1 year after application near LaPryor (Table 2). The response of guayacan to any given application rate was highly variable during the first growing season after application. Most plants exhibited some degree of chlorosis and many completely defoliated and refoliated at least three times during the year following treatment. The defoliation cycle was apparently regulated by rainfall, with defoliation occurring after significant precipitation followed by repienishment of the canopies as the soil gradually dried. At 2 and 3 years after application, defoliation levels of guayacan were increased as compared to the year after treatment, with the higher rates resulting in a canopy reductions of greater than $70 \%$. At 3 years after application, $4 \%$ of the guayacan were killed by $1.12 \mathrm{~kg} / \mathrm{ha}$ active ingredient of tebuthiuron, $28 \%$ by $2.24 \mathrm{~kg} / \mathrm{ha}, 37 \%$ by $3.36 \mathrm{~kg} / \mathrm{ha}$, and $55 \%$ were killed by the highest rate of the herbicide. Near Tilden, the guayacan was undamaged at 18 months after application of 1 or $2 \mathrm{~kg} / \mathrm{ha}$. No guayacan was present on the research near Sinton. Guayacan is a desirable species for white-tailed decr (Odocoileus virginianus) but occurs in excessive quantities on much of the South Texas Plains and Coastal Prairie. Therefore, achieving only partial control of this species was considered desirable.

Control of twisted acacia was also improved the second year

Table 3. Canopy reduction (\%) guajillo and blackbrush acacia populations killed (\%) by July 20,1977 , after two application rates (active ingredient) of pelleted tebuthiuron with ground equipment on May 18, 1976, near Pearsall, Texas. ${ }^{1}$

\section{Guajillo}

Tebuthiuron Canopy rate $(\mathrm{kg} / \mathrm{ha})$
Blackbrush acacia

Canopy

reduction

Killed

$0 \mathrm{a}$

$21 \mathrm{~b}$

$97 \mathrm{c}$

$\begin{array}{cc}0 \mathrm{a} & 0 \mathrm{a} \\ 47 \mathrm{~b} & 21 \mathrm{~b} \\ 97 \mathrm{c} & 72 \mathrm{c}\end{array}$

1 Means within a column followed by the same letter are not signiticantly different at the $95 \%$ level according to Duncan's new multiple range test.
Table 4. Canopy reduction (\%) of whitebrush, spiny hackberry, and desert yaupon at 1,2 , and 3 years after aerial application of various rates (active ingredient) of pelleted tebuthiuron near LaPryor, Texas, in 1974.

\begin{tabular}{|c|c|c|c|c|c|c|}
\hline \multirow[b]{2}{*}{ Species } & \multirow{2}{*}{$\begin{array}{l}\text { Year after } \\
\text { treatment }\end{array}$} & \multirow{2}{*}{0} & \multicolumn{4}{|c|}{ Tebuthiuron rate $(\mathrm{kg} / \mathrm{ha})^{\prime}$} \\
\hline & & & 1.12 & 2.24 & 3.36 & 4.48 \\
\hline \multirow[t]{3}{*}{ Whitebrush } & 1 & $0 \mathrm{a}$ & $100 \mathrm{~b}$ & $100 \mathrm{~b}$ & $100 \mathrm{~b}$ & $100 \mathrm{~b}$ \\
\hline & 2 & $0 \mathrm{a}$ & $96 \mathrm{~b}$ & $98 \mathrm{~b}$ & $99 \mathrm{~b}$ & $99 \mathrm{~b}$ \\
\hline & 3 & $0 \mathrm{a}$ & $90 \mathrm{~b}$ & $90 \mathrm{~b}$ & $99 \mathrm{~b}$ & $99 \mathrm{~b}$ \\
\hline \multirow[t]{3}{*}{ Spiny hackberry } & y 1 & $0 \mathrm{a}$ & $91 \mathrm{bcd}$ & $96 \mathrm{~cd}$ & $98 \mathrm{~d}$ & $94 \mathrm{~cd}$ \\
\hline & 2 & $0 \mathrm{a}$ & $77 \mathrm{bc}$ & $99 \mathrm{~d}$ & $99 d$ & $99 \mathrm{~d}$ \\
\hline & 3 & $0 \mathrm{a}$ & $74 \mathrm{~b}$ & 86 bcd & $85 \mathrm{bcd}$ & $97 \mathrm{~d}$ \\
\hline \multirow[t]{3}{*}{ Desert yaupon } & 1 & $0 \mathrm{a}$ & 86 de & $90 \mathrm{e}$ & $87 \mathrm{de}$ & $91 \mathrm{e}$ \\
\hline & 2 & $0 \mathrm{a}$ & $66 \mathrm{bcd}$ & $63 \mathrm{bc}$ & $59 \mathrm{bc}$ & $69 \mathrm{~cd}$ \\
\hline & 3 & $0 \mathrm{a}$ & $48 \mathrm{~b}$ & $6 \mathrm{abc}$ & $60 \mathrm{bc}$ & $73 \mathrm{cde}$ \\
\hline
\end{tabular}

' Means within a species followed by the same letter are not significantly different at the $95 \%$ level.

after tebuthiuron application compared to the first year (Table 2). The lower herbicide rates, 1.12 and $2.24 \mathrm{~kg} / \mathrm{ha}$, reduced the twisted acacia canopies by 32 to $57 \%$ at 2 years after treatment, whereas the higher rates resulted in canopy reductions of 73 to $76 \%$. Canopy reduction of twisted acacia at 3 years after application was no different than after 2 years, regardless of application rate. Percentage of twisted acacia killed by 1.12 to $3.36 \mathrm{~kg} / \mathrm{ha}$ of tebuthiuron in the experiment near LaPryor was $4 \%$ or less. However, $51 \%$ of the plants were killed by the high rate after 3 years. Twisted acacia near Tilden was unaffected at 18 months after application of tebuthiuron at 1 or $2 \mathrm{~kg} / \mathrm{ha}$.

No twisted acacia existed on the Sinton site but there was a heavy stand of huisache. At 19 months after treatment, canopy reduction of huisache was 51 and $81 \%$ where 2 and $3.36 \mathrm{~kg} / \mathrm{ha}$ were applied, respectively. The lower rate killed $24 \%$ of the huisache, and $66 \%$ were killed by the higher rate.

Guajillo, another woody species desirable in certain quantities as deer browse, was present at the LaPryor and Pearsall locations. At 1.12 and $2.24 \mathrm{~kg} / \mathrm{ha}$, active ingredient tebuthiuron reduced the guajillo canopies by 55 to $76 \%$ the year after treatment with no increased control by the second or third year after treatment near LaPryor (Table 2). However, at the higher tebuthiuron rates, defoliation of guajillo exceeded $90 \%$ at 1 and 2 years after treatment. By 3 years after application of 3.36 and $4.48 \mathrm{~kg} / \mathrm{ha}$ of tebuthiuron, average canopy reduction was 70 and $84 \%$. respectively. At 3 years after application, $20 \%$ of the guajillo population was killed by the lowest tebuthiuron rate, $29 \%$ by $2.24 \mathrm{~kg} / \mathrm{ha}, 42 \%$ by $3.36 \mathrm{~kg} / \mathrm{ha}$, and $64 \%$ by the highest rate.

Response of guajillo to $1.5 \mathrm{~kg} / \mathrm{ha}$ tebuthiuron applied with ground equipment near Pcarsall (Table 3 ) was similar to the response to $1.12 \mathrm{~kg} / \mathrm{ha}$ near LaPryor (Table 2). The higher rate near Pearsall completely defoliated the guajillo population and $97 \%$ of the plants were showing no signs of life at the time of evaluation (Table 3 ).

Whitebrush, a serious management problem on some of the most productive rangelands of South Texas, is difficult to control with conventional chemical and mechanical methods. However, whitebrush is apparently highly susceptible to tebuthiuron based on results of this study. At all application rates, the canopies of whitebrush were completely defoliated at 1 year after treatment near LaPryor (Table 4). A few plants showed signs of recovery after 2 years but average defoliation levels exceeded $95 \%$ regardless of tebuthiuron rate. Although recovery of whitebrush was evident at 3 years after application of tebuthiuron at the lower rates, near complete control resulted 
where the higher rates were applied. Although no whitebrush was present on the study site near Sinton, it dominated the Tilden study area. At 18 months after treatment with $1 \mathrm{~kg} / \mathrm{ha}$ near Tilden, whitebrush canopy reduction was $88 \%$ and $25 \%$ of the plants were dead. Where tebuthiuron was applied at $2 \mathrm{~kg} / \mathrm{ha}$, the whitebrush population was completely controlled at the final evaluation. Since whitebrush may occur in solid stands, tebuthiuron has excellent potential for improvement of rangeland infested with this troublesome species.

Spiny hackberry is another common component of South Texas mixed-brush stands which is usually only partially controlled by conventional aerial sprays. Like whitebrush, spiny hackberry was apparently highly susceptible to tebuthiuron. The year after application, defoliation of spiny hackberry exceeded $90 \%$ regardless of tebuthiuron rate (Table 4). At 2 years after application, defoliation was near complete where at least $2.24 \mathrm{~kg} / \mathrm{ha}$ of tebuthiuron werc applicd. Although some recovery of spiny hackberry was evident 3 years after application of 1.12 to $3.36 \mathrm{~kg} / \mathrm{ha}$ near LaPryor, average canopy reduction was $97 \%$ where $4.48 \mathrm{~kg} / \mathrm{ha}$ were applied. Where the highest herbicide rate was applied, $91 \%$ of the spiny hackberry was killed. Average canopy reduction of spiny hackberry near Sinton was 68 and $93 \%$ where 2 and $3.36 \mathrm{~kg} / \mathrm{ha}$ of tebuthiuron were applied, respectively. Where $2 \mathrm{~kg} / \mathrm{ha}$ were applied, $30 \%$ of the plants were killed and $90 \%$ were killed by the high rate after 19 months. Near Tilden, spiny hackberry canopies were reduced by 56 and $100 \%$, and 47 and $100 \%$ of the plants were killed where 1 and $2 \mathrm{~kg} / \mathrm{ha}$ of tebuthiuron were applied, respectively.

Desert yaupon responded favorably to tebuthiuron application the year after treatment near LaPryor (Table 4). However, regardless of application rate, recovery of desert yaupon was evident during the second growing season and defoliation was less than $70 \%$ following application of the highest rate. Canopy reduction after 3 years was no different than after 2 years, regardless of application rate. No desert yaupon occurred on the study sites near Tilden and Sinton.

Blackbrush acacia near Pearsall responded similarly to guajillo with $47 \%$ canopy reduction after treatment with 1.5 $\mathrm{kg} / \mathrm{ha}$ of tebuthiuron and $97 \%$ canopy reduction after treatment with the high rate (Table 3 ). Based on these results and observations from near LaPryor, at least 2 to $3 \mathrm{~kg} / \mathrm{ha}$ of tebuthiuron may be required for moderate to high control levels of blackbrush acacia.

Several other species were present on the study areas but their distribution did not allow statistical analyses of their responses to tebuthiuron. Observation of several of these species at all locations indicate that Berlandier wolfberry may be highly susceptible to $2.24 \mathrm{~kg} / \mathrm{ha}$ or more tebuthiuron since canopy reduction usually exceeded $80 \%$ and more than $25 \%$ of the plants were killed. Lotebush, Texas colubrina, ceniza, and javalinabrush appeared to be moderately susceptible with 50 to $80 \%$ overall canopy reduction but with less than $25 \%$ of the plants killed by $2.24 \mathrm{~kg} / \mathrm{ha}$. Lime pricklyash (Zanthoxylum fagara) and Texas persimmon appeared to have a low order of susceptibility to the herbicide with pricklypear and tasajillo virtually unaffected by high rates of application.

Based on results of these studies, tebuthiuron appears to hold excellent potential for control of several problem woody species on South Texas rangeland. Although not highly effective on honey mesquite, the herbicide may have use following application of other brush control methods which have controlled the honey mesquite and released troublesome secondary species. Tebuthiuron appears highly promising for control of whitebrush since the species often occurs in almost solid stands on the more productive rangeland soils of South Texas. Although this study was not designed to compare formulations, there was no apparent difference in brush control with the pellets containing 10 or $20 \%$ active ingredient.

\section{Literature Cited}

Bovey, R.W., H.T. Morton, J.R. Baur, J.D. Diaz-Colon, C.C. Dowler, and S.K. Lehman, 1969. Granular herbicides for woody plant control. Weed Sci. 17'538-541.

Bovey, R.W., R.E. Meyer, and J.R. Baur. 1975. Evaluation of tebuthiuron for woody plant control. Abstr., Weed Sci. Soc. Amer., No. 54. p 22-23.

Cottam, G., and J.T. Curtis. 1956. The use of distance measures in phystosociological sampling. Ecology 37:451-460.

Hoffman, G.O., and J.D. Dodd. 1967. How to whip pricklypear. Texas Agr. Prog. 13(3):16-18.

Kearney, P.C., and D.D. Kaufman. 1969. Degradation of Herbicides. Marcel Dekker, Inc., New York. 394 p.

Scifres, C.J. 1972. Redberry juniper control with soil-applied herbicides. J. Range Manage. 25:308-310.

Scifres, C.J., and M.M. Kothmann. 1976. Site relations, regrowth characteristics and control of lotebush with herbicides. J. Range Manage. 29:154-156.

Scifres, C.J., J.L. Mutz, and C.H. Meadors. 1977. Response of range vegetation to grid placement and acrial application of karbutilate. Weed Sci. 25: (In press).

Scifres, C.J. 1975a. Systems for improving Macartney rose-infested coastal prairie rangeland. Texas Agr. Exp. Sta. MP-1225. 12 p.

Scifres, C.I. 1975b. Texas persimmon distribution and control with individualplant treatments. Texas Agr. Exp. Sta. Bull. 1157. 12 p. 